\title{
REACH THE UNREACHED -IIRS OUTREACH PROGRAM FOR ENHANCED LEARNING TO ALL
}

\author{
Y.V.N. Krishna Murthy ${ }^{a}$, P.L.N. Raju, *, S.K. Srivastav ${ }^{a}$, Harish Karnatak ${ }^{a}$, Prasun Kumar Gupta ${ }^{a}$, Mahadevaswamy. M ${ }^{a}$, Janardan \\ Vishwakarma $^{\mathrm{a}}$
}

${ }^{a}$ Indian Institute of Remote Sensing, Indian Space Research Organisation, Dehradun, India - plnraju @ gmail.com

\author{
Commission VI, WG VI/2
}

KEY WORDS: EDUSAT, Distance Learning, Tele-education, Internet, Remote Sensing, GIS and GNSS

\begin{abstract}
:
With the advent of Information and Communication Technology and improved broadband internet connectivity has enhanced the scope of learning any time anywhere, going beyond the traditional classroom approach. To support distance learning, Indian Space Research Organisation, Government of India has launched dedicated communication satellite called EDUSAT in 2004. The satellite is widely used for variety of applications like Tele-education, Tele-medicine, Village Resource Centres, mobile satellite services, disaster management support and television broadcasting educating farmers for agriculture and other purposes. One of the prime applications of EDUSAT satellite is tele-education at various levels (i.e. school level/UG /PG level) by different ministries / autonomous organizations / departments/institutions/universities in India effectively utilized the EDUSAT for Tele-education.
\end{abstract}

The initial focus of IIRS was to use EDUSAT/INSAT 4CR satellite for distance learning but extended the scope to use broadband internet so that access to large number of institutions/universities /individuals with little cost the User. IIRS distance learning program initiated in 2007 and successfully conducted 12 programs in the last eight years. The first course was attended from twelve universities and the number of institutions /universities increased manifold. The thirteenth course is progress with more than 210 institutions /universities /departments /individuals with more than 3200 number of participants attending the program live and interactive. IIRS program is unique and interactive and demand is increasing not only universities but among research institutions, user departments and individuals.

\section{INTRODUCTION}

\subsection{Background}

Indian Institute of Remote Sensing (IIRS) as a constituent Unit of Indian Space Research Organisation (ISRO), Department of Space, Government of India. Formerly known as Indian Photointerpretation Institute (IPI), founded in 1966, the Institute boasts to be the first of its kind in entire South-East Asia. While nurturing its primary endeavour to build capacity among the user community by training mid-career professionals, the Institute has enhanced its capability and evolved many training \& education programmes in the field of Remote Sensing, Geoinformatics and GPS Technology for Natural Resources, Environmental and Disaster Management that are tuned to meet the requirements of various target groups, ranging from fresh graduates to policy makers including academia (www.iirs.gov.in). Till 2006 IIRS focus was on contact basis training and education programs (Dadhwal et.al, 2007 \& Raju et. al, 2007). With the advent of EDUSAT (dedicated satellite launched in September 2004 from ISRO with a purpose of providing quality education, vocational training for skill development and to reach the unreached places like remote and inaccessible locations in India. IIRS launched pilot project and started EDUSAT satellite based distance learning outreach program on Remote Sensing and Geoinformatics to address the needs of Users who can receive IIRS outreach programs directly from their place of working / place of study without coming to IIRS.
Since the launch of EDUSAT communication satellite many networks have been established at national and state level started using it for various programs for variety of purposes as listed below:

- School level education

- Higher education at university

- Technical education through engineering colleges

- Vocational training programs

- Skill development for career opportunities

- Distance learning programs through Open universities

Table 1 shows the list of institutions /organisations extensively using the EDUSAT satellite for distance learning programs.

\begin{tabular}{|c|c|c|}
\hline $\begin{array}{l}\mathbf{S} . \\
\mathbf{N}\end{array}$ & Institute / Organisation & $\begin{array}{l}\text { Purpose of Tele- } \\
\text { education }\end{array}$ \\
\hline 1 & $\begin{array}{lr}\begin{array}{l}\text { Central } \\
\text { Educational }\end{array} & \text { Institute } \\
\text { Technology } \\
\text { (CIET), National Council of } \\
\text { Educational Research and } \\
\text { Training (NCERT) and } \\
\begin{array}{l}\text { Department } \\
\text { Education }\end{array} \text { (DSEL) School and } \\
\text { Literacy, Ministry of Human } \\
\begin{array}{l}\text { Resource } \\
\text { (MHRD) }\end{array}\end{array}$ & $\begin{array}{l}\text { Development of } \\
\text { National Repository } \\
\text { of Open Educational } \\
\text { Resources } \\
\text { (NROER), combined } \\
\text { effort of CIET, } \\
\text { NCERT and DSEL, } \\
\text { MHRD and make it } \\
\text { available for free } \\
\text { access and learning }\end{array}$ \\
\hline
\end{tabular}

\footnotetext{
* Corresponding author.
} 


\begin{tabular}{|c|c|c|}
\hline 2 & $\begin{array}{l}\text { Indira Gandhi National Open } \\
\text { University (IGNOU) }\end{array}$ & $\begin{array}{l}\text { One of the largest } \\
\text { networks established } \\
\text { for open and } \\
\text { interactive learning } \\
\text { with large number of } \\
\text { study Centres spread } \\
\text { across India }\end{array}$ \\
\hline 3 & $\begin{array}{lr}\text { All India } & \text { Council for } \\
\text { Technical } & \text { Education } \\
\text { (AICTE) } & \end{array}$ & $\begin{array}{l}\text { The network was } \\
\text { established for } \\
\text { Engineering } \\
\text { Colleges with } \\
\text { delivery of subjects } \\
\text { from expert faculty }\end{array}$ \\
\hline 4 & $\begin{array}{l}\text { Consortium for Education } \\
\text { Communication, University } \\
\text { Grants Commission (CEC- } \\
\text { UGC) }\end{array}$ & $\begin{array}{l}\text { Higher education at } \\
\text { university level , } \\
\text { producing } \\
\text { educational material } \\
\text { and broadcasting } \\
\text { using EDUSAT and } \\
\text { interaction with } \\
\text { users through large } \\
\text { number of Satellite } \\
\text { Interactive Terminals }\end{array}$ \\
\hline 5 & $\begin{array}{l}\text { VigyanPrasar, Department of } \\
\text { Science \& Technology, } \\
\text { Government of India }\end{array}$ & $\begin{array}{lr}\text { Popularizing } & \text { science } \\
\text { through } & \text { books, } \\
\text { science } & \text { CDs, videos } \\
\text { and } & \text { broadcasting } \\
\text { through } & \text { EDUSAT } \\
\text { national } & \text { beam } \\
\text { network } & \\
\end{array}$ \\
\hline 6 & $\begin{array}{l}\text { State primary and secondary } \\
\text { education }\end{array}$ & $\begin{array}{lr}\text { EDUSAT is } & \text { utilized } \\
\text { for many } & \text { parallel } \\
\text { networks } & \text { under } \\
\text { regional } & \text { beam } \\
\text { service } & \text { with } \\
\text { ROT/SIT set up } \\
\text { established } \\
\text { different States for } \\
\text { school at } \\
\text { education }\end{array}$ \\
\hline
\end{tabular}

Table 1: Institutions/ Organisations using EDUSAT based distance learning programs.

\section{EVOLUTION OF IIRS OUTREACH PROGRAM}

\subsection{Initial Phase}

National Natural Resource Management System (NNRMS) standing committee on Training and Technology (SC-T) has funded IIRS outreach program in a pilot mode for three years initially during 2006-09 to conduct EDUSAT based distance learning program. The first batch consists of 12 Universities and participants of 349 in the first course conducted in 2007. The table-2 show the list of universities and number of participants attended the course on Basics of Remote Sensing (RS), Geographical Information System (GIS) and Global Navigation System (GPS).

\begin{tabular}{|r|l|l|}
\hline S. N & $\begin{array}{l}\text { Name Participating } \\
\text { University/Institution }\end{array}$ & $\begin{array}{l}\text { No. of } \\
\text { Participants }\end{array}$ \\
\hline 1 & Anna Univ., Chennai & 12 \\
\hline 2 & Banasthali Univ., Jaipur & 62 \\
\hline 3 & JamiaMilliaIslamia, New Delhi & 12 \\
\hline
\end{tabular}

\begin{tabular}{|r|l|r|}
\hline 4 & JNU, New Delhi & 25 \\
\hline 5 & Kashmir Univ., Srinagar & 22 \\
\hline 6 & Madurai Kamaraj Univ., Madurai & 26 \\
\hline 7 & Mysore Univ., Mysore & 59 \\
\hline 8 & NIT, Warangal & 21 \\
\hline 9 & Pune Univ., Pune & 61 \\
\hline 10 & Rajiv Gandhi Univ., Doimukh & 14 \\
\hline 11 & Sagar Univ., Sagar & 21 \\
\hline 12 & Tripura University, Tripura & 14 \\
\hline & Total No. of Participants & $\mathbf{3 4 9}$ \\
\hline & $\begin{array}{l}\text { Total No. of } \\
\text { Universities/Institutions } \\
\text { Participated }\end{array}$ & \\
\hline
\end{tabular}

Table 2. List universities participated in First IIRS Outreach Program conducted in 2007

\subsection{Developmental Phase}

The demand for the IIRS outreach program increased many fold over the years by joining universities and institutions and benefiting from the program. Total thirteen programs were conducted in a span of eight years during 2007 to 2014. Started with one program per year initially and expanded the program to two courses in a year. One common course i.e. basic course on RS, GIS \& GPS is conducted every year and one special course on different topics based on demands and technological trends. Success story of IIRS outreach programs are show cased at various national and international forums (Raju et. al, 2010, 2011, 2012, Gupta et.al, 2011). There is continuous increase in number of universities / institutions participation and increase in participation. Table-3 is showing list of universities and number of participants, showing upward trends.

\begin{tabular}{|l|l|l|l|l|}
\hline $\mathbf{S .}$ & Course Name & $\begin{array}{l}\text { Duratio } \\
\mathbf{n}\end{array}$ & $\begin{array}{l}\text { No } \\
\text { of } \\
\text { Parti } \\
\text { cipa } \\
\text { nts }\end{array}$ & $\begin{array}{l}\text { No. of } \\
\text { Univ./Inst } \\
\text { Participat } \\
\text { ed }\end{array}$ \\
\hline 1 & $\begin{array}{l}\text { Basics of "RS, GIS \& } \\
\text { GPS" }\end{array}$ & $\begin{array}{l}\text { Jan-Apr } \\
2007\end{array}$ & 249 & 12 \\
\hline 2 & $\begin{array}{l}\text { Basics of "RS, GIS \& } \\
\text { GPS" }\end{array}$ & $\begin{array}{l}\text { Sep-Dec } \\
2007\end{array}$ & 951 & 31 \\
\hline 3 & $\begin{array}{l}\text { Basics of "RS, GIS \& } \\
\text { GPS" }\end{array}$ & $\begin{array}{l}\text { Aug-Nov } \\
2008\end{array}$ & 915 & 23 \\
\hline 4 & $\begin{array}{l}\text { Basics of "RS, GIS \& } \\
\text { GPS" }\end{array}$ & $\begin{array}{l}\text { Aug-Oct } \\
2009\end{array}$ & 935 & 32 \\
\hline 5 & $\begin{array}{l}\text { Basics of "RS, GIS \& } \\
\text { GPS" }\end{array}$ & $\begin{array}{l}\text { Oct-Dec } \\
2010\end{array}$ & 1101 & 31 \\
\hline 6 & $\begin{array}{l}\text { Advance Course on } \\
\text { "Advances } \\
\text { Geoinformatics" in }\end{array}$ & $\begin{array}{l}\text { Feb-Mar } \\
2010\end{array}$ & 171 & 10 \\
\hline 7 & $\begin{array}{l}\text { Basics of "RS, GIS \& } \\
\text { GPS" }\end{array}$ & $\begin{array}{l}\text { Aug-Nov } \\
2011\end{array}$ & 1519 & 31 \\
\hline 8 & $\begin{array}{l}\text { Advance Course on } \\
\text { "Hyperspectral } \\
\text { Remote Sensing" }\end{array}$ & $\begin{array}{l}\text { Feb-Mar } \\
2012\end{array}$ & 651 & 21 \\
\hline 9 & $\begin{array}{l}\text { Basics of "RS, GIS \& } \\
\text { GPS" }\end{array}$ & $\begin{array}{l}\text { Aug-Oct } \\
2012\end{array}$ & 1072 & 37 \\
\hline 10 & Advance Course on & Feb-Mar & 1033 & 41 \\
\hline & & & \\
\hline
\end{tabular}




\begin{tabular}{|c|l|l|l|l|}
\hline & $\begin{array}{l}\text { "Geo-web Services - } \\
\text { Technology \& } \\
\text { Applications" }\end{array}$ & 2013 & & \\
\hline 11 & $\begin{array}{l}\text { Basics of "RS, GIS \& } \\
\text { GNSS" }\end{array}$ & $\begin{array}{l}\text { Aug-Nov } \\
2013\end{array}$ & 1982 & 76 \\
\hline 12 & $\begin{array}{l}\text { Advance Course on } \\
\text { "Microwave } \\
\text { (SAR)Remote } \\
\text { Sensing for Natural } \\
\text { Resources" }\end{array}$ & 2014 & 2160 & 108 \\
\hline 13 & $\begin{array}{l}\text { Basics of "RS, GIS \& } \\
\text { GNSS" }\end{array}$ & $\begin{array}{l}\text { Aug-Nov } \\
2014\end{array}$ & 3495 & 217 \\
\hline & Total & \multicolumn{2}{|l|}{} \\
\hline
\end{tabular}

Table 3. List of universities and number of participants

\subsection{Current Phase}

With sustained growth and demand for the outreach program IIRS is in the process of establishing start of art studio cum classroom which will serve for the following purposes:

$>$ Addressing students of IIRS as well as outreach program participants simultaneously

$>$ Interact with participants at IIRS and distance location participants simultaneously

$>$ Establish one to one connectivity with specific institute in video conference mode and conduct specific tailor made programs

$>$ Broadcasting popular talks from eminent persons and received across many centres.

The established studio will enable IIRS to expand its program of two hours in a day to full day programs of 4 to 8 hours depending as per the demand.

\section{METHODS OF DELIVERY}

\subsection{Satellite based Outreach program}

The classrooms spread across India are connected through VSAT with IIRS for receiving IIRS outreach program and interact after the lecture. There are around 45 classroom setups of CEC-UGE, CIET-NCERT, IGNOU, AICTE and VigyanPrasar established at Universities / Schools / study Centres/Engineering Colleges and receives our programs through Train net based Learning Management System (Figure 1). It is better approach than the earlier used open source free VLC streaming system (Figure 2) where the quality of presentation material are very poor.

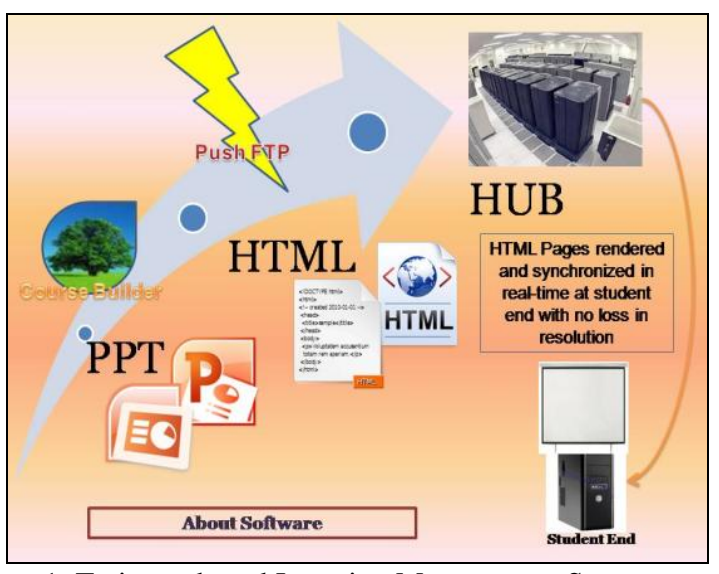

Figure 1. Train net based Learning Management System
Though Train net LMS is better than the VLC but it has also limitations like delaying the popping up of presentation material if they are rich image contents. It also does not handle the animations and interactive presentations.

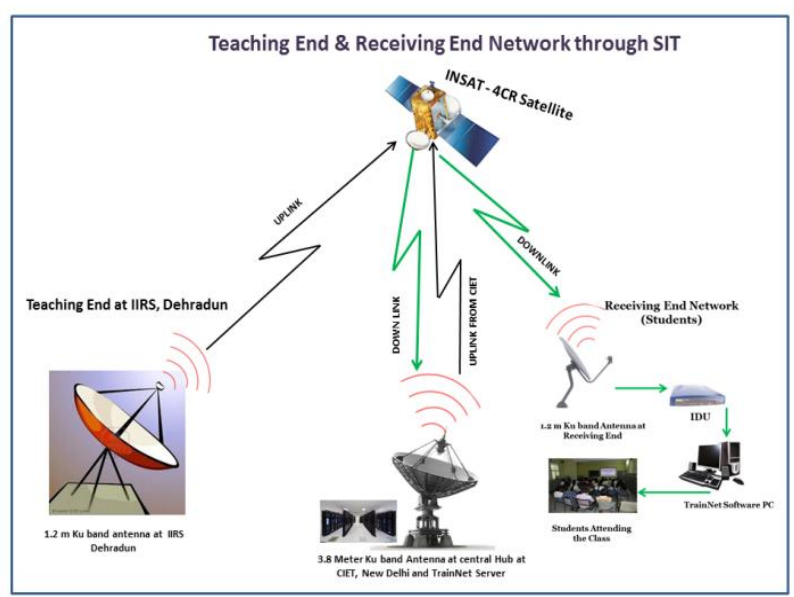

Figure 2. VLC streaming system

\subsection{Internet based Distance Learning Outreach Program}

IIRS outreach programs are also delivered through internet by using A-VIEW system developed by Amrita University funded by Ministry of Human Resources Development (MHRD). It is better than VLC as well as Trainnet based approach as far as quality of content, delivery mechanism and interactivity with the connected users (Figure 3). Only limitation is internet bandwidth at the user location. The user should have a minimum of 2 mbps connectivity for good reception and interaction.

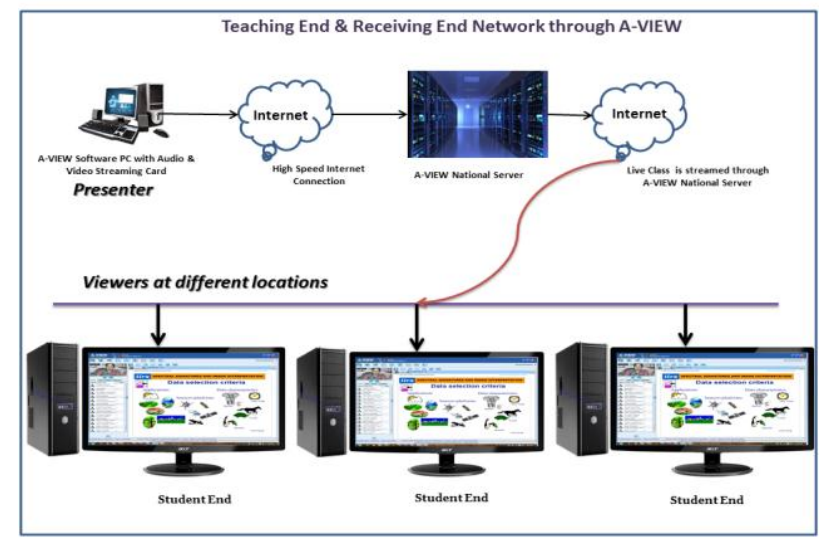

Figure 3. Internet based Distance Learning Outreach Program

\subsection{IIRS E-Learning Program}

To learn any time anywhere, IIRS has launched exclusive internet based e-learning program from 2014 (www.elearning.iirs.gov.in). It is made free for all who are tenth class pass if one wanted to learn Remote Sensing and Geoinformation Science. One has to pay the tuition fees for different certificate programs one /four months etc. Full details of e-learning program under separate paper presented at ISPRS TC VIII mid symposium 2014. 


\subsection{Feedback of IIRS Outreach Programs}

To monitor the assimilation and general views, feedback is taken from participants and coordinators separately. The feedback of coordinators on qualitative aspects of the program is shown in Figure 4.

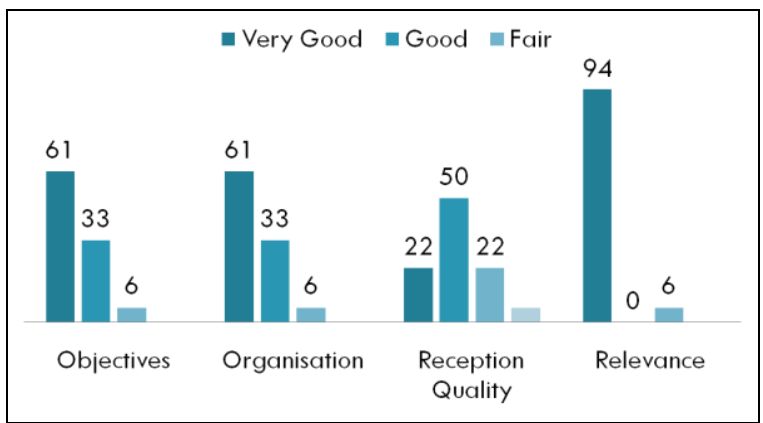

Figure 4. Feedback of $10^{\text {th }}$ and $11^{\text {th }}$ IIRS Outreach Programs

The feedback from participants on technical aspects such as delivery and curriculum is shown in Figure 5.

\section{Do you think the lectures were interesting and all the questions were answered by the faculty?}

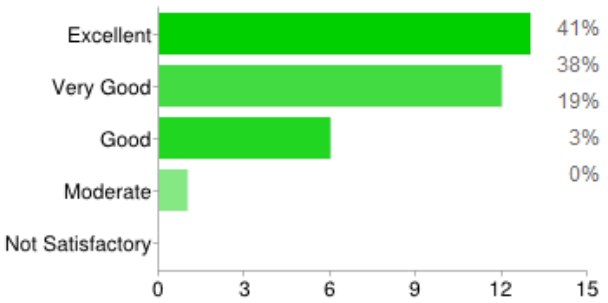

How do you rate the course curriculum \& delivery mechanism

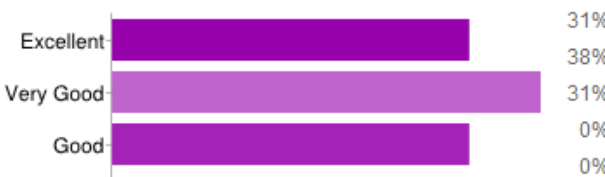

Moderate-

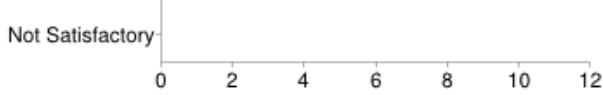

Methods - Lecture Discussions

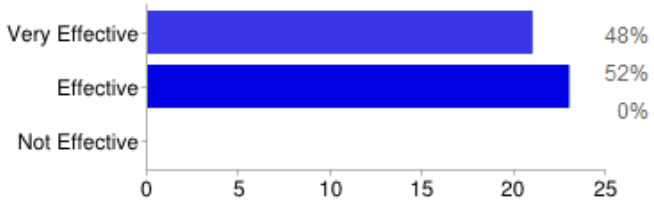

Methods - Demonstrations

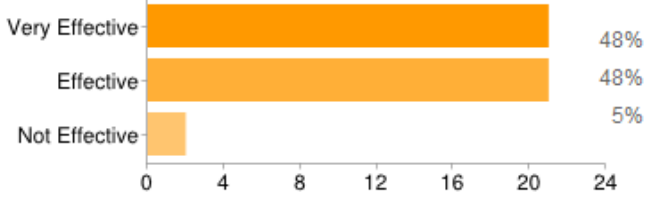

Figure 5. Feedback by participants on technical aspects
A dedicated session for discussing feedback on the course is also conducted at the IIRS User Interaction Meet - 2014. The overall summary of the meet is given below:

$>$ Separate certificates for all 4 modules (RS, GIS etc.)

$>$ Slides to be limited to 30 nos.

$>$ Coordinator must conduct a field visit - IIRS module coordinator to facilitate

$>$ Programme/Schedule for full year to be released by March of current year

$>2$ weeks' time gap between individual modules

\section{THROUGHPUT OF IIRS OUTREACH PROGRAMS}

IIRS conducted thirteen courses in the last eight years. Out of which nine of them were basic courses and four are special and advanced courses. The program started with a modest beginning. Started with 12 no. of universities in the beginning and it has expanded to 217 No. of Universities and participation of 3000 participants in one single course. So far 16234 attended and benefitted from IIRS outreach programs (Table 3). Year wise list of participating universities / institutions and no of participants are shown in Figure 6 \& Figure 7.

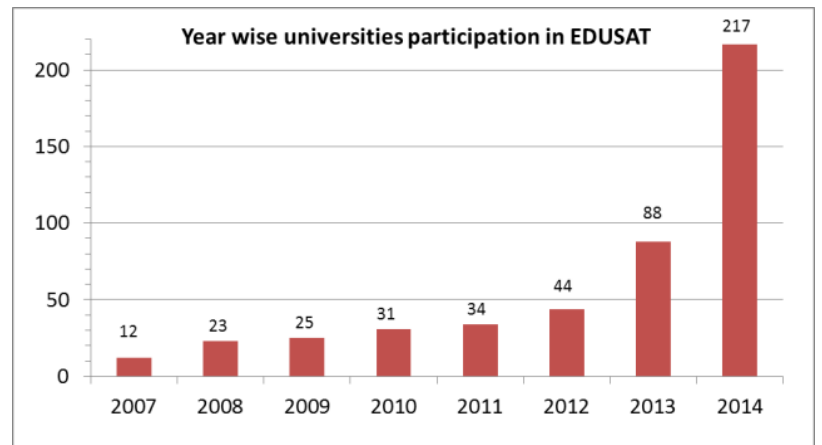

Figure 6. Year wise list of Universities participation

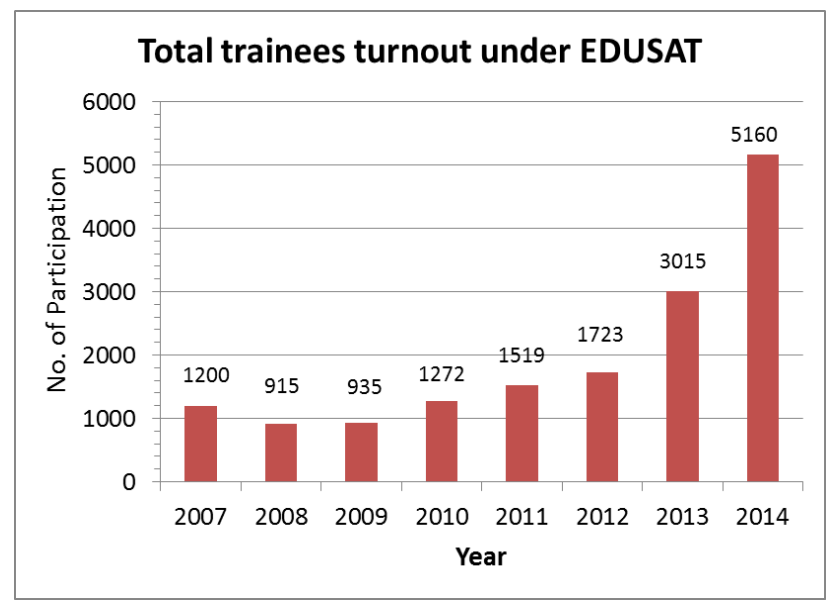

Figure 7. Year wise total trainee turnout

Initial focus was exclusively for universities. With growing demand the programs were extended to other users like research institutions, government departments and private and open to individuals etc. (Figure 8) 


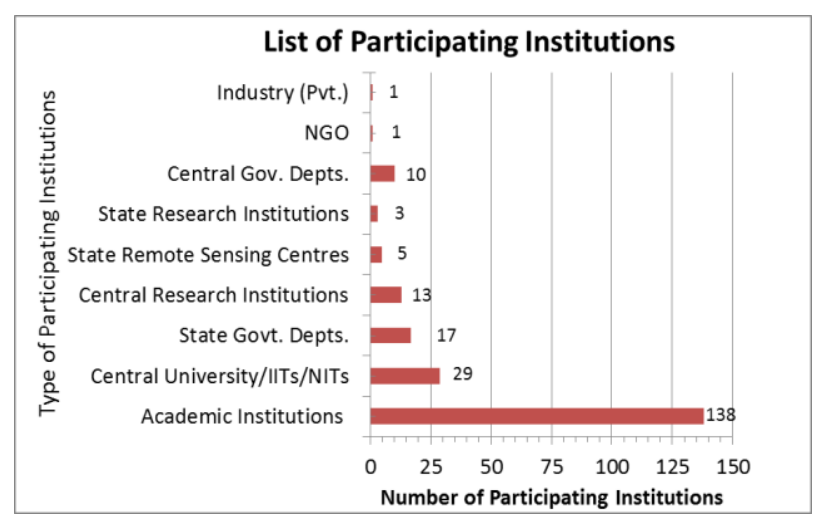

Figure 8. Type of Participating Institutions

\section{CONCLUSIONS}

IIRS outreach program is made open for all for free learning so as to reach all like satellite based connected users and others who can connect through Internet. The outreach program is successful in terms its accessibility and learning. Future plan are to further expand with many tailor programs to User Departments, programs to South-east Asia and developing countries and provide capacity building to ISRO /other project initiatives through IIRS outreach program so as to benefit maximum number.

\section{REFERENCES}

Raju, P.L.N., Gupta, P.K., and Roy, P.S., 2011. "Satellite Based Live and Interactive Distance Learning Program in the field of Geoinformatics - A Perspective of Indian Institute of Remote Sensing, India." ISPRS WG VI/1,2 Workshop E-Learning 2011 within ACRS. 4-6 October 2011, Taipei, Taiwan

Gupta, P.K., Raju, P.L.N., and Roy, P.S., 2011. "User Response Analysis of IIRS Geomatics EDUSAT Distance Learning Program and Future Challenges." ISPRS VI/4 International Workshop on Multinational Geomatics Capacity Building Achievements and Challenges", IIRS, Dehradun, India, April 78, 2011

Raju, P.L.N., and Gupta, P.K., 2012, "Satellite based Education and Training in Remote Sensing and GeoInformation: an E-Learning Approach to Meet the Growing Demands in India." International Archives of Photogrammetry, Remote Sensing and Spatial InformationScience, XXXIXB6(Vol), 25-29, 2012 doi:10.5194/isprsarchives-XXXIX-B625-2012.

Raju, P.L.N., Dadhwal, V.K., Verma, Mamta., Jeganathan, C., Kumar, Minakshi., and Kumar, Anil., 2008, "Indian Experiences for University Level Capacity Building in Geomatics using EDUSAT Satellite", The International Archives of the Photogrammetry, Remote Sensing and Spatial Information Sciences. Vol. XXXVII. Part B6a. Beijing 2008, pp 229-234

Raju, P.L.N., and Dadhwal, V.K., 2010, "IIRS Perspective on Lessons from Implementation of a Cross Border Joint Education Program", ISPRS Archives - Volume XXXVIII Part 6, 2011, ISPRS Mid-Term Symposium Commission VI CrossBorder Education for Global Geo-information June 2-4, 2010, Enschede, The Netherlands, Editor(s): Martien Molenaar, TsehaieWoldai, SaskiaTempelman
Raju, P.L.N., Dadhwal, V.K., and Jeganathan, C., 2007, "GIS Education and Training at Indian Institute of Remote Sensing", GIS Development Asia Pacific, Mach 2007, Vol 11, Issue 3.

Raju, P.L.N., and Dadhwal, V.K., 2007. Four decades of capacity building in applications of space-based earth observation and Geoinformatics at Indian Institute of Remote Sensing, Proceedings of 58th International Astronautical Congress, organized at NRSA, Hyderabad during Sept. 24-28, 2007. IAC-07-E1.I.08.

\section{ACKNOWLEDGEMENTS}

IIRS outreach program is one of the unique and successful programs continued since 2007 with active support of Indian Space Research Organisation. The authors are thankful to Secretary, ISRO and Chairman, DOS and Director, IIRS for their support and encouragement to conduct the program regularly and helping to expand to reach as maximum as possible. This popularly known as EDUSAT program is technically supported by Satellite Communication and Navigation Program (SCNP) Office, Development of Education and Communication Unit (DECU), Consortium for Educational Communication (CEC), UGC, Amrita Virtual Interactive eLearning World (A-VIEW) Team from Amrita University and Central Institute of Educational Technology (CIET), NCERT and team members of IIRS studio technical team and faculty supported for the success of the outreach programs. The authors are thankful to all of them and others who also supported directly or indirectly for the program. 